\title{
DESIGN AND STUDY THE EFFECTIVENESS OF ENGINE CYLINDER FIN WITH VARIABLE GEOMETRY AND MATERIAL
}

\author{
N.Srinivasa Rao ${ }^{1}$, G.V. Subhash ${ }^{2}$, K. Ashok Kumar ${ }^{3}$, B.N. Malleswara Rao ${ }^{4}$ \\ ${ }^{1}$ Assistant.Professor, Mechanical Department, Shri Vishnu Engineering College for women, A.P, India \\ ${ }^{2}$ Assistant.Professor, Mechanical Department, Shri Vishnu Engineering College for women, A.P, India \\ ${ }^{3}$ Assistant.Professor, Mechanical Department, Shri Vishnu Engineering College for women, A.P, India \\ ${ }^{4}$ Assistant.Professor, Mechanical Department, Shri Vishnu Engineering College for women, A.P, India
}

\begin{abstract}
In automobiles, the engine cylinder is subjected to high temperature variations and thermal stresses .So as to cool the engine cylinder, fins are mounted on the engine cylinder to increase the rate of heat transfer. By doing thermal analysis on the engine cylinder fins you can know the rate of heat transfer inside the cylinder. The main objective of the project is to analyze the thermal behavior of cylinder fins by varying geometries, materials and thickness. In this project $2.5 \mathrm{~mm}$ and $3 \mathrm{~mm}$ thickness of fins are considered for various fin geometries and they are designed using AUTO CAD 2016.Thermal analysis on the fins is done by using ANSYS WORKBENCH. In our project we have taken materials aluminum alloy 6063 and aluminum alloy 7068 instead of general material aluminum alloy 204. The geometries circular, rectangular and trapezoidal fins with Aluminum alloy 204, Aluminum alloys 6063 and 7068 of thickness $2.5 \mathrm{~mm} \& 3 \mathrm{~mm}$ are compared on the basis of total rate of heat flux \& effectiveness. It is found that aluminum alloy 6063 of circular geometry with $2.5 \mathrm{~mm}$ thickness is having more rate of heat flux \&effectiveness.
\end{abstract}

Keywords: Aluminum alloys 6063, Aluminum alloys 7068, Aluminum alloy 204, ANSYS WORKBENCH, AUTO CAD 2016.

\section{INTRODUCTION}

The term extended surface is commonly used in reference to a solid that experiences energy transfer by conduction and convection between its boundary and surroundings, a temperature gradient in $\mathrm{x}$ direction sustains heat transfer by conduction internally at the same time, there is heat dissipation by convection into an ambient at $\mathrm{T}_{\infty}$ from its surface at temperature $T_{S}$, given as

$$
\mathrm{Q}=\mathrm{h} \text { As }\left(\mathrm{T}_{\mathrm{S}^{-}} \mathrm{T}_{\infty}\right)
$$

Where $\mathrm{h}=$ convection heat transfer coefficient

$\mathrm{A}_{\mathrm{S}}=$ Heat transfer area of a surface

When the temperatures $T_{S}$ and $T_{\infty}$ are fixed by design considerations, there are only two ways to increase the heat transfer rate:(i) to increase the convection coefficient $\mathrm{h}$, (ii) to increase the surface area A. in this situations, in which an increase in $\mathrm{h}$ is not practical or economical, because increasing h may require the installation of pump or fan or replacing existing one with larger one, the heat transfer rate can be increased by increasing the surface area. For heat transfer from a hot liquid to a gas, through a wall, the value of heat transfer coeffient on the gas side is usually very less compared to that liquid side $\left(\mathrm{h}_{\mathrm{gas}} \ll<<<\mathrm{h}_{\text {liquid }}\right)$.to compensate low heat transfer coefficient, the surface area on the gas side may be extended for a given temperature difference between surface and its surroundings. These extended surfaces are called fins. The fins are normally thin strips of highly conducting metals such as aluminium, copper, brass etc. The fins enhance the heat transfer rate from a surface by exposing larger surface area to convection. The fins are used on the surface where the heat transfer Coefficient is very low. Total heat produced by the combustion of charge in the engine cylinder may not convert into useful power at the crankshaft. so loss of heat approximately at the cylinder walls is $30 \%$ due to cooling. If this heat is not removed from the cylinders it would result in the preignition of the charge and also damage the cylinder material. as well as the lubricant may also burn away, so that causing the piston may seizing keeping the above factor in view , it is observed that suitable heat must be maintained in the cylinder. So that excess heat removed by adding the fins to the cylinder walls.

\subsection{Classification of Fins}

Based on the geometry of fins. Fins can be classified into three type .They are

1. Longitudinal fins

2. Annular fins

3. Pin- fin or spine fins

Longitudinal fins: It is a straight rectangular fin attached to a plane wall. It may be of uniform cross-sectional area, or its area may vary along its length to form a triangular, parabolic or trapezoidal shape. 


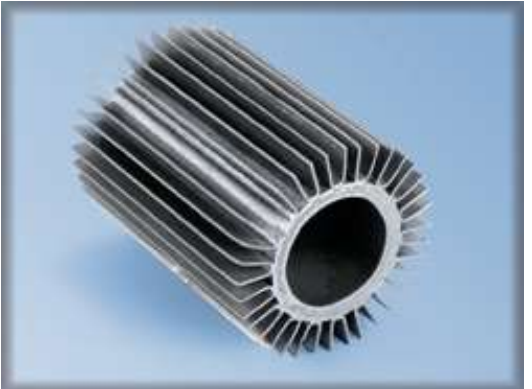

Fig -1.1 longitudinal fin

Annular fins: An angular fin is a fin that is circumferentially attached to a cylinder and its cross-section varies with radius from center line of cylinder.

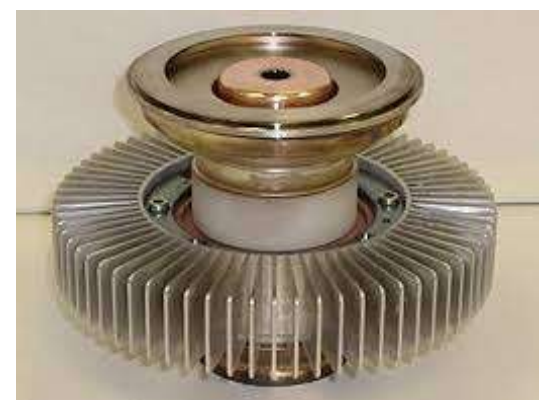

Fig -1.2 Annular Fin

Spine or pin-fin: A pin-fin or spine is an extended surface of circular cross-section whose diameter is much smaller than its length. The pin fins may also be uniform or nonuniform cross-section.

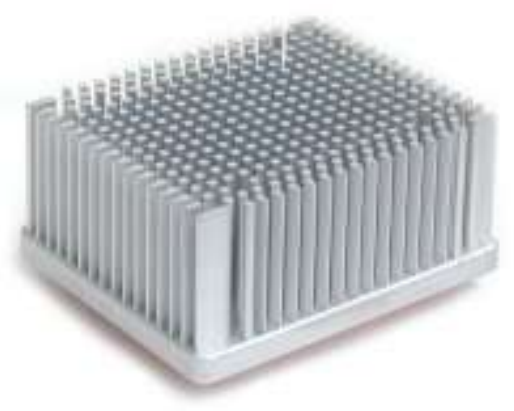

Fig -1.3 spine or pin-fin

\subsection{Applications of Fins}

- It is Mounted on engine cylinder to cool the engine

- It is also used in refrigeration system

- It is used in car radiators

- It is also used in electrical transformers and motors

\section{FIN MATERIALS}

Most commonly used material for manufacturing of fins is aluminum alloy. Now we are replacing present aluminum alloy with Aluminum alloy 6063 and Aluminum alloy 7068.

\section{Chemical Composition of Aluminum Alloy}

Following Table is the composition for Aluminium alloy
Table -2.1 Chemical composition of AL Alloy

\begin{tabular}{|c|c|}
\hline Element & Weight \% \\
\hline $\mathrm{C}$ & 0.25 \\
\hline $\mathrm{Mn}$ & 0.9 \\
\hline $\mathrm{P}$ & 0.03 \\
\hline $\mathrm{S}$ & 0.04 \\
\hline $\mathrm{Si}$ & $0.15-0.30$ \\
\hline $\mathrm{Mo}$ & $0.45-0.60$ \\
\hline $\mathrm{Ni}$ & 0.05 \\
\hline
\end{tabular}

\section{Chemical Composition Aluminum Alloy 6063}

Following Table is the Chemical composition for Aluminium alloy 6063

Table -2.2 Chemical composition of AL alloy 6063

\begin{tabular}{|c|c|}
\hline Element & Weight \% \\
\hline Aluminum & Balance \\
\hline Chromium & 0.1 \\
\hline Copper & 0.1 \\
\hline Iron & 0.35 \\
\hline Magnesium & $0.45-0.9$ \\
\hline Manganese & 0.1 \\
\hline Silicon & $0.2-0.6$ \\
\hline Titanium & 0.1 \\
\hline Zinc & 0.1 \\
\hline
\end{tabular}

\section{Chemical Composition of Aluminum Alloy 7068}

Following Table is the chemical composition of Aluminium alloy 7.68

Table -2.3 Chemical composition of Aluminium 7068

\begin{tabular}{|c|c|}
\hline Element & Weight \% \\
\hline Zinc & 8.3 \\
\hline Magnesium & 3 \\
\hline Copper & 2.4 \\
\hline Iron & 0.15 \\
\hline Zirconium & 0.15 \\
\hline Silicon & 0.12 \\
\hline Manganese & 0.1 \\
\hline Titanium & 0.1 \\
\hline Chromium & 0.05 \\
\hline Aluminum & 85.58 \\
\hline
\end{tabular}

\section{Properties of Materials}

Table -2.4 Properties of selected Materials

\begin{tabular}{|l|l|l|l|}
\hline Aluminium alloy & 204 & 6063 & 7068 \\
\hline Tensile Strength (Mpa) & 331 & 330 & 710 \\
\hline Thermal conductivity (w/m-k) & 120 & 200 & 190 \\
\hline Specific heat $\left(\mathbf{J} / \mathbf{g}^{\mathbf{0}} \mathbf{C}\right)$ & 0.963 & 0.9 & 0.963 \\
\hline Density & 2.8 & 2.7 & 2.8 \\
\hline \multirow{2}{*}{ Melting point $\left.\mathbf{(}^{\mathbf{0}} \mathbf{C}\right)$} & $529-$ & $616-$ & $476-$ \\
& 649 & 654 & 635 \\
\hline
\end{tabular}




\section{DIMENSIONS AND ANALYSIS OF FINS}

Dimensions for fins and cylinder have been taken from the standard dimensions. We have made some changes to the standard dimensions according to our project. We have changed the thickness, length of the fins and pitch of fins. Following Table is the considered dimensions for design. All Dimensions are in $\mathrm{mm}$.

Table -3.1 Selected Dimensions

\begin{tabular}{|l|c|}
\hline Cylinder Inner Diameter & 66 \\
\hline Cylinder Outer Diameter & 78 \\
\hline Thickness of Fin & 2.5 \\
\hline Length of Fin & 27 \\
\hline Pitch of Fin & 10 \\
\hline Length of Cylinder & 120 \\
\hline
\end{tabular}

\subsection{Result of Aluminum Alloy 204 Circular Fin}

\section{Body with $3 \mathrm{~mm}$ and $2.5 \mathrm{~mm}$ Thickness}

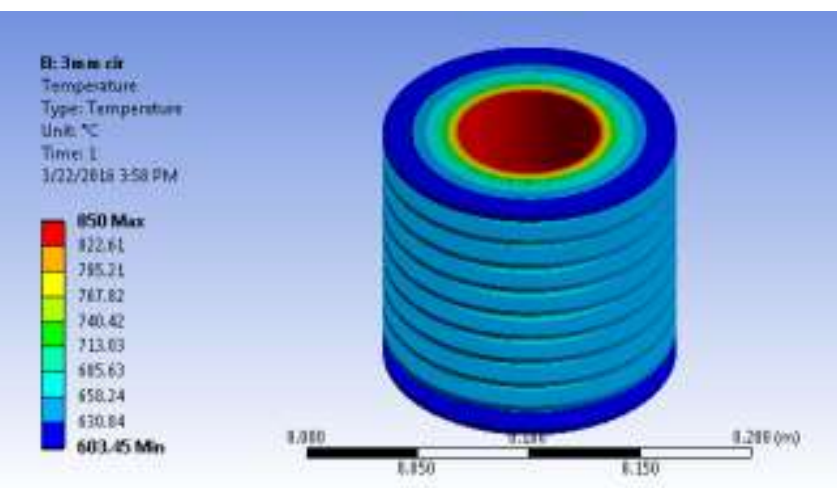

Fig -3.1: Temperature for Aluminum alloy 204 at $3 \mathrm{~mm}$ thickness.

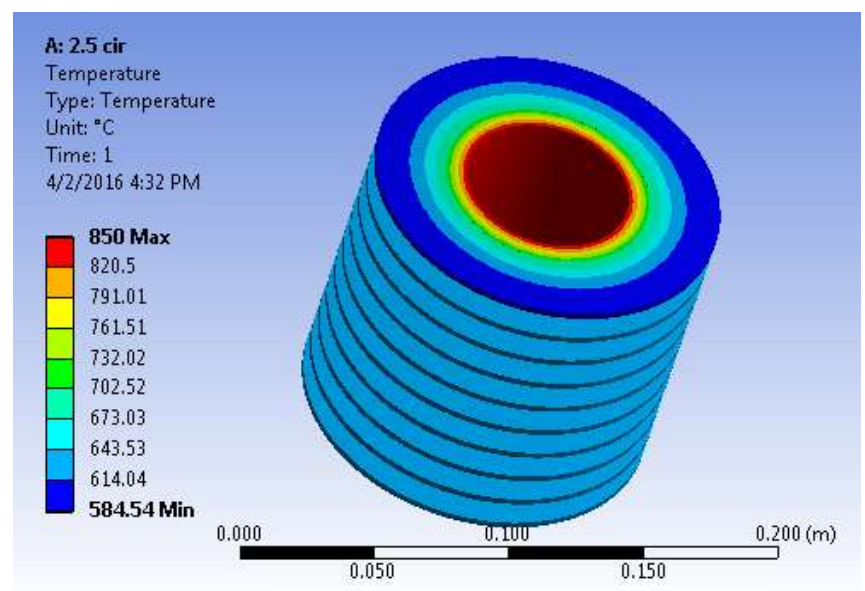

Fig -3.2: Temperature for aluminum alloy 204 at $2.5 \mathrm{~mm}$ thickness

We have observed that the temperature change within the fin of $3 \mathrm{~mm}$ thickness is from $850^{\circ} \mathrm{C}$ to $603.4^{\circ} \mathrm{C}$ by the flowing of air over the fin. Which is having a temperature gradient of $29^{\circ} \mathrm{C}$.We have observed that the temperature change within the fin of $2.5 \mathrm{~mm}$ thickness is from $850^{\circ} \mathrm{C}$ to $584.54^{\circ} \mathrm{C}$ by the flowing of air over the fin. Which is having a temperature gradient of $29.5^{\circ} \mathrm{C}$.

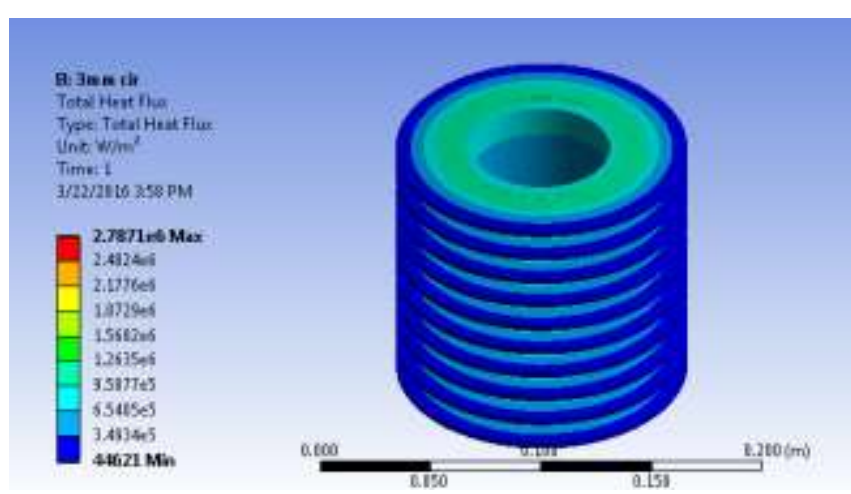

Fig -3.3: Total heat flux for Aluminum alloy 204 at $3 \mathrm{~mm}$ thickness.

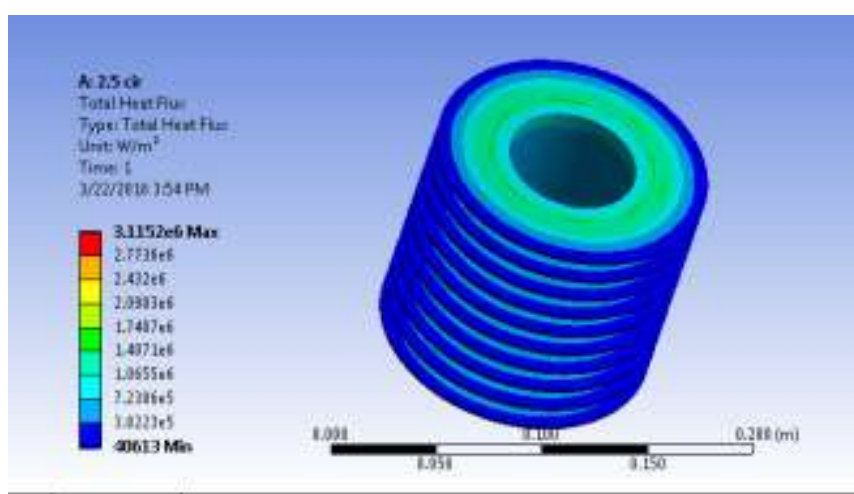

Fig -3.4: Total heat flux for Aluminum alloy 204 at $2.5 \mathrm{~mm}$ thickness.

We have observed that the total heat flux change within the fin of $3 \mathrm{~mm}$ thickness is from $2.7871 * 10^{6} \mathrm{w} / \mathrm{m}^{2}$ to 44621 $\mathrm{w} / \mathrm{m}^{2}$ by the flowing of air over the fin and the difference of total heat flux is $0.3047 \mathrm{w} / \mathrm{m}^{2}$. We have observed that the total heat flux change within the fin of $2.5 \mathrm{~mm}$ thickness is from $3.115^{*} 10^{6} \mathrm{w} / \mathrm{m}^{2}$ to $27086 \mathrm{w} / \mathrm{m}^{2}$ by the flowing of air over the fin and the difference of total heat flux is $0.3416 \mathrm{w} / \mathrm{m}^{2}$.

\subsection{Result of Aluminum Alloy 204 Rectangular Fin}

\section{Body with $3 \mathrm{~mm}$ and $2.5 \mathrm{~mm}$ Thickness.}

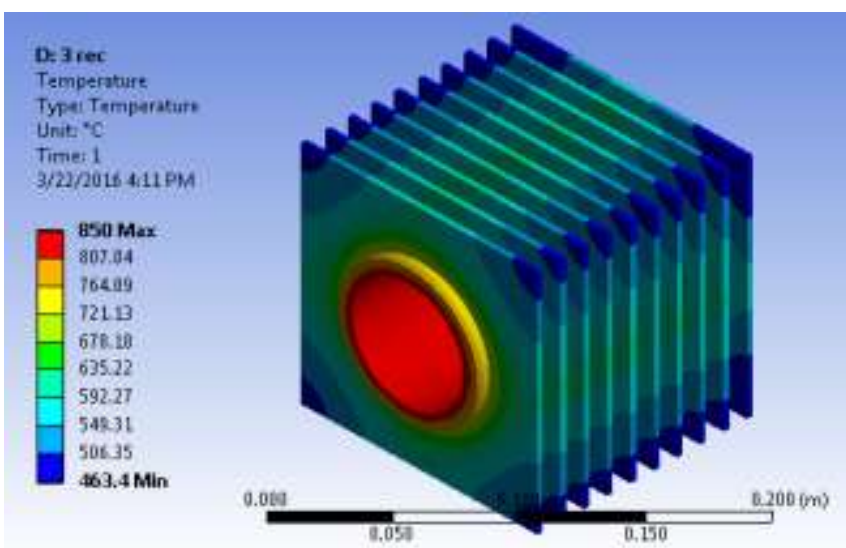

Fig -3.5: Temperature for Aluminum alloy 204 at 3mm thickness. 


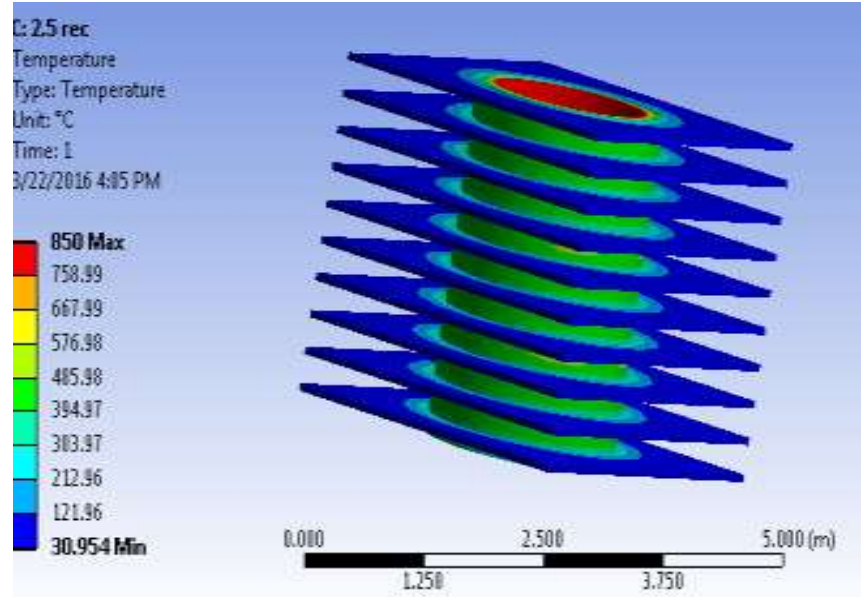

Fig -3.6: Temperature for aluminum alloy 204 at $2.5 \mathrm{~mm}$ thickness.

We have observed that the temperature change within the fin of $3 \mathrm{~mm}$ thickness is from $850^{\circ} \mathrm{C}$ to $463.4^{\circ} \mathrm{Cby}$ the flowing of air over the fin. Which is having a temperature gradient of $42.96^{\circ} \mathrm{c}$. We have observed that the temperature change within the fin of $2.5 \mathrm{~mm}$ thickness is from $850^{\circ} \mathrm{C}$ to $30.950^{\circ} \mathrm{C}$ by the flowing of air over the fin. Which is having a temperature gradient of $91.01^{\circ} \mathrm{C}$.

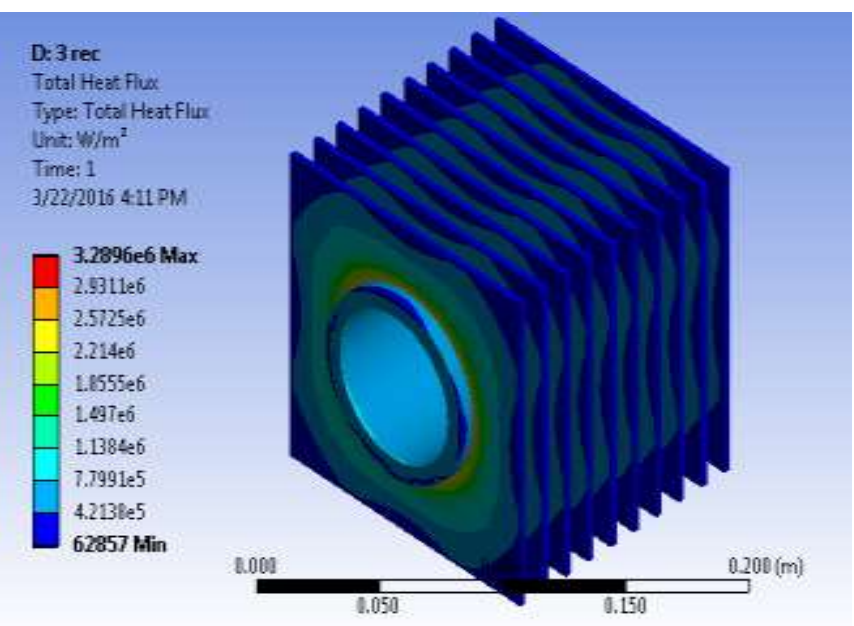

Fig -3.7: Total heat flux for Aluminum alloy 204 at $3 \mathrm{~mm}$ thickness.

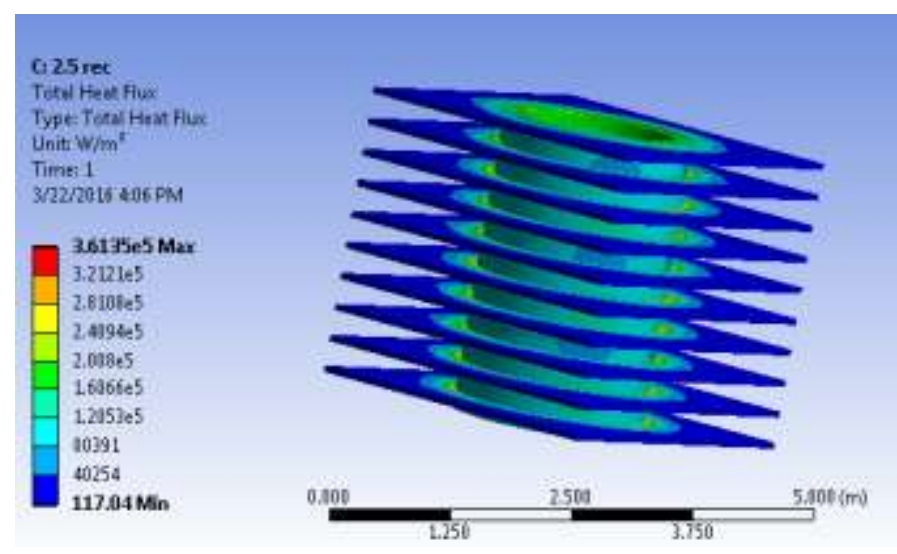

Fig -3.8: Total heat flux for Aluminum alloy 204 at $2.5 \mathrm{~mm}$ thickness.
We have observed that the total heat flux change within the fin of $3 \mathrm{~mm}$ thickness is from $3.2896^{*} 10^{6} \mathrm{w} / \mathrm{m}^{2}$ to 62857 $\mathrm{w} / \mathrm{m}^{2}$ by the flowing of air over the fin and the difference of total heat flux is $0.3047 \mathrm{w} / \mathrm{m} 2$. We have observed that the total heat flux change within the fin of $2.5 \mathrm{~mm}$ thickness is from $3.115^{*} 10^{6} \mathrm{w} / \mathrm{m}^{2}$ to $27086 \mathrm{w} / \mathrm{m}^{2}$ by the flowing of air over the fin and the difference of total heat flux is $0.3416 \mathrm{w} / \mathrm{m}^{2}$.

\subsection{Result of Aluminum Alloy204 Trapezoidal Fin}

\section{Body with 3mmand $2.5 \mathrm{~mm}$ Thickness}

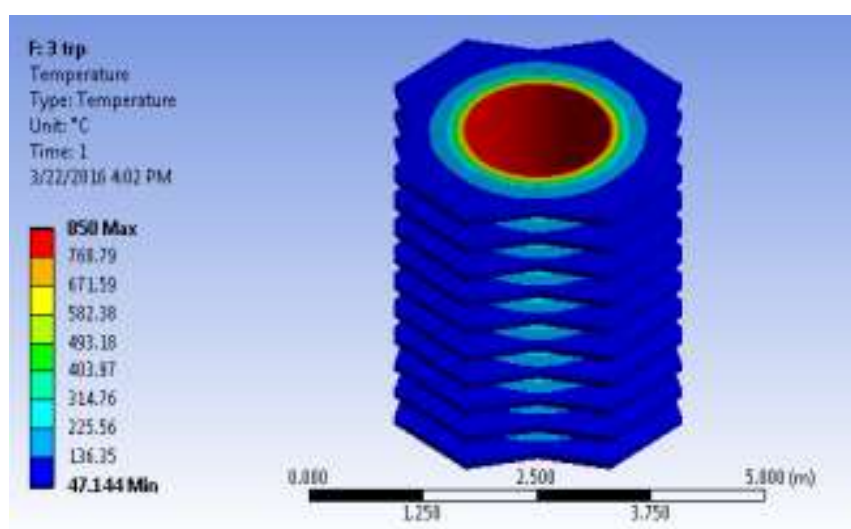

Fig -3.9: Temperature for Aluminum alloy 204 at 3mm thickness.

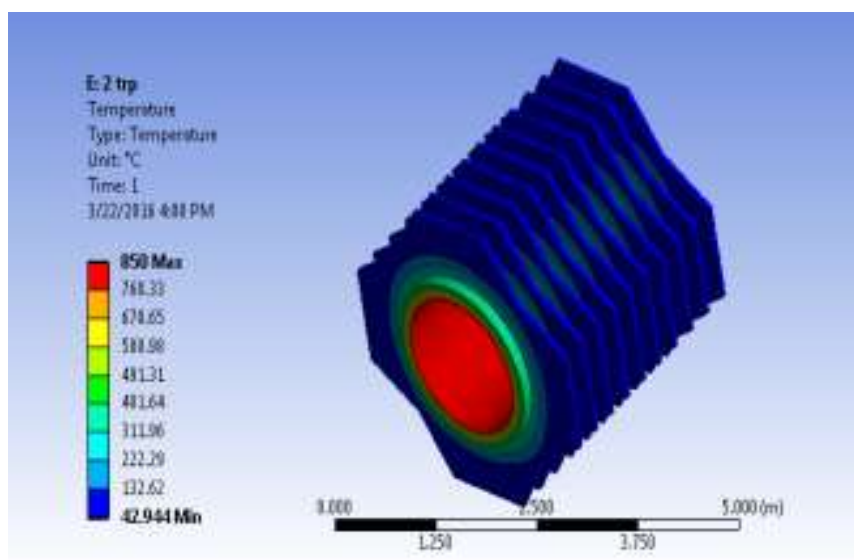

Fig -3.10: Temperature for aluminum alloy 204 at 2.5mmthickess.

We have observed that the temperature change within the fin of $3 \mathrm{~mm}$ thickness is from $850^{\circ} \mathrm{C}$ to $47.14^{\circ} \mathrm{C}$ by the flowing of air over the fin. Which is having a temperature gradient of $89.21^{\circ} \mathrm{C}$. We have observed that the temperature change within the fin of $2.5 \mathrm{~mm}$ thickness is from $850^{\circ} \mathrm{C}$ to 42.944 ${ }^{\circ} \mathrm{C}$ by the flowing of air over the fin. Which is having a temperature gradient of $89.67^{\circ} \mathrm{C}$. 


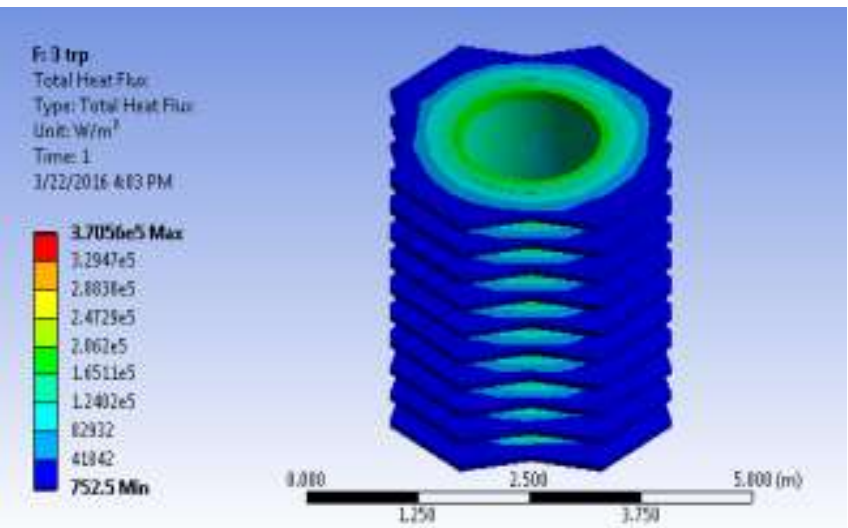

Fig -3.11: Total heat flux for Aluminum alloy 204 at $3 \mathrm{~mm}$ thickness.

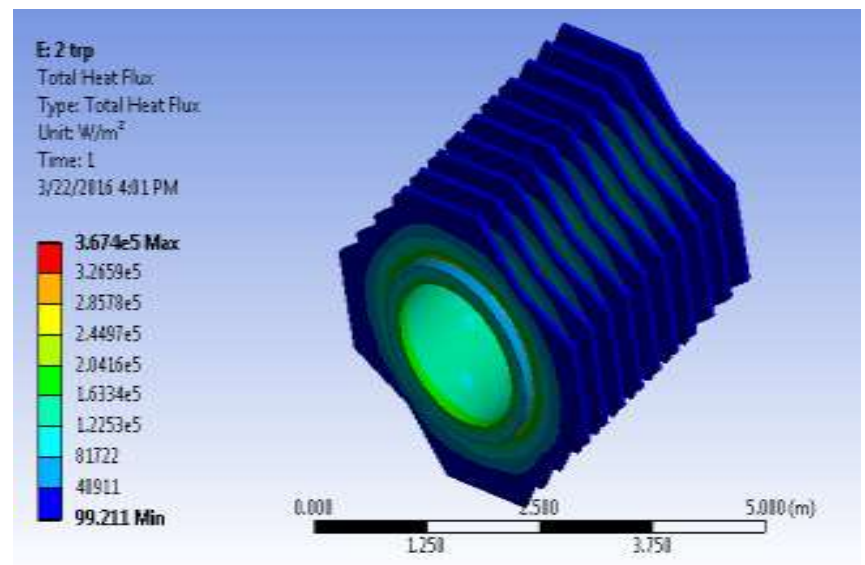

Fig -3.12: Total heat flux for Aluminum alloy 204 at 2.5 mm thickness.

We have observed that the total heat flux change within the fin of $3 \mathrm{~mm}$ thickness is from $3.7056^{*} 10^{6} \mathrm{w} / \mathrm{m}^{2}$ to 752.5 $\mathrm{w} / \mathrm{m}^{2}$ by the flowing of air over the fin and the difference of total heat flux is $0.4109 \mathrm{w} / \mathrm{m}^{2}$. We have observed that the total heat flux change within the fin of $2.5 \mathrm{~mm}$ thickness is from $3.674 * 10^{6} \mathrm{w} / \mathrm{m}^{2}$ to $99.211 \mathrm{w} / \mathrm{m}^{2}$ by the flowing of air over the fin and the difference of total heat flux is $0.4081 \mathrm{w} / \mathrm{m}^{2}$.

\subsection{Result of Aluminum alloy 6063Circular Fin}

\section{Body with $3 \mathrm{~mm}$ and $2.5 \mathrm{~mm}$ Thickness}

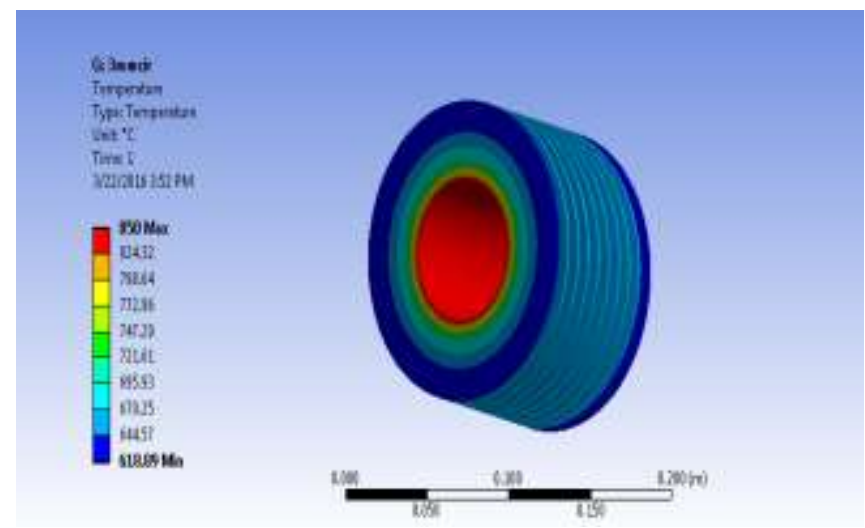

Fig -3.13: Temperature for Aluminum alloy 6063 at 3mm thickness .

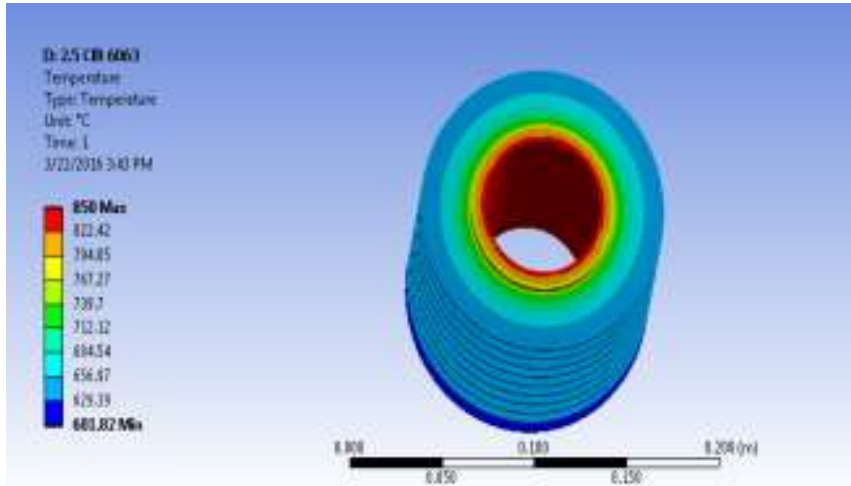

Fig -3.14: Temperature for aluminum alloy 6063 at $2.5 \mathrm{~mm}$ thickness.

We have observed that the temperature change within the fin of $3 \mathrm{~mm}$ thickness is from $850^{\circ} \mathrm{C}$ to $618.89^{\circ} \mathrm{Cby}$ the flowing of air over the fin. Which is having a temperature gradient of $25.68^{\circ} \mathrm{C}$. We have observed that the temperature change within the fin of $2.5 \mathrm{~mm}$ thickness is from $850^{\circ} \mathrm{C}$ to $601.82^{\circ} \mathrm{C}$ by the flowing of air over the fin. Which is having a temperature gradient of $27.58^{\circ} \mathrm{C}$.

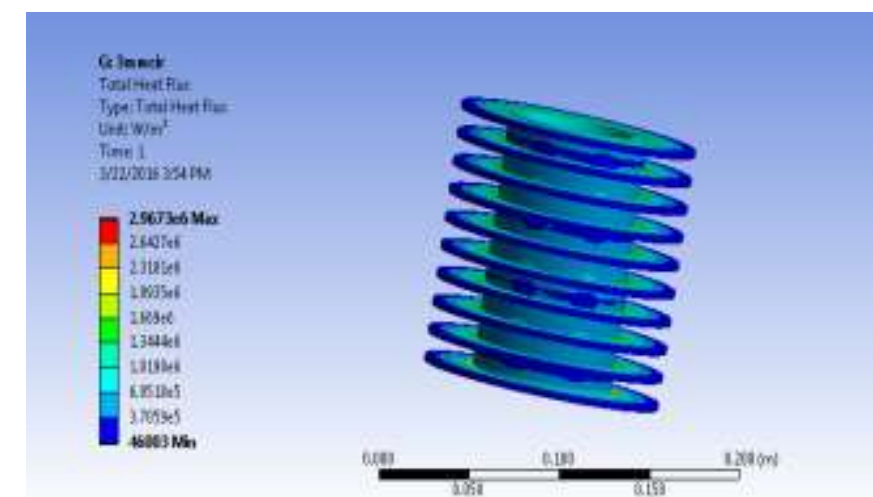

Fig - 3.15: Total heat flux for Aluminum alloy 6063 at $3 \mathrm{~mm}$ thickness.

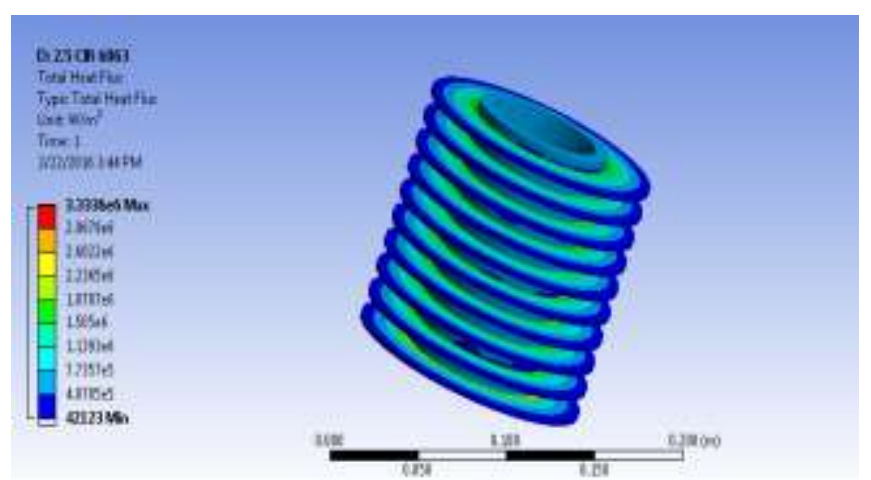

Fig -3.16: Total heat flux for Aluminum alloy 6063 at 2.5 $\mathrm{mm}$ thickness.

We have observed that the total heat flux change within the fin of $3 \mathrm{~mm}$ thickness is from $2.9673^{*} 10^{6} \mathrm{w} / \mathrm{m}^{2}$ to $46003 \mathrm{w} / \mathrm{m}^{2}$ by the flowing of air over the fin and the difference of total heat flux is $0.3246 \mathrm{w} / \mathrm{m}^{2}$. We have observed that the total heat flux change within the fin of $2.5 \mathrm{~mm}$ thickness is from $3.336 * 10^{6} \mathrm{w} / \mathrm{m}^{2}$ to $42123 \mathrm{w} / \mathrm{m}^{2}$ by the flowing of air over the fin and the difference of total heat flux is $0.3657 \mathrm{w} / \mathrm{m}^{2}$. 


\subsection{Result of Aluminum alloy 6063 Rectangular}

\section{Fin Body with $3 \mathrm{~mm}$ and $2.5 \mathrm{~mm}$ Thickness}

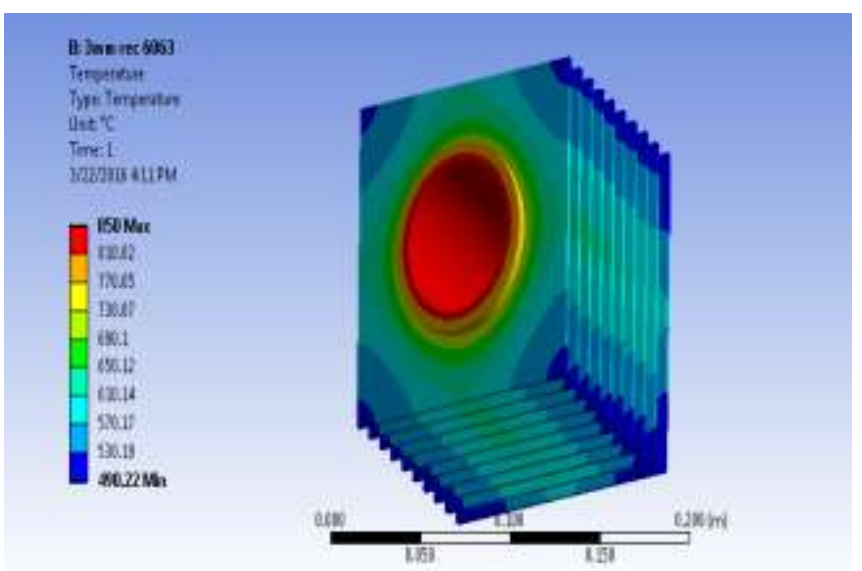

Fig -3.17: Temperature for Aluminum alloy 6063 at $3 \mathrm{~mm}$ thickness

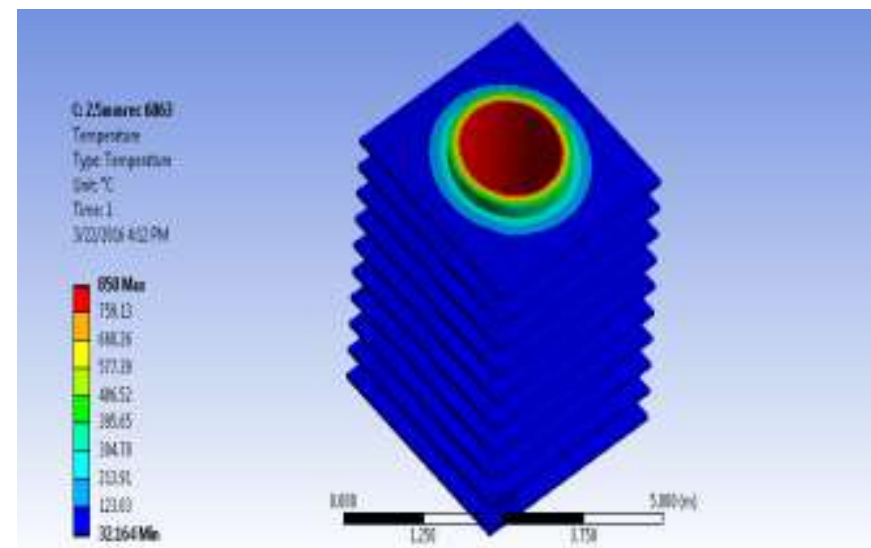

Fig -3.18: Temperature for aluminum alloy 6063 at $2.5 \mathrm{~mm}$ thickess.

We have observed that the temperature change within the fin of $3 \mathrm{~mm}$ thickness is from $850^{\circ} \mathrm{C}$ to $490.22^{\circ} \mathrm{C}$ by the flowing of air over the fin. Which is having a temperature gradient of $39.98^{\circ} \mathrm{c}$. We have observed that the temperature change within the fin of $2.5 \mathrm{~mm}$ thickness is from $850^{\circ} \mathrm{C}$ to $32.164^{\circ} \mathrm{C}$ by the flowing of air over the fin. Which is having a temperature gradient of $90.87^{\circ} \mathrm{C}$.

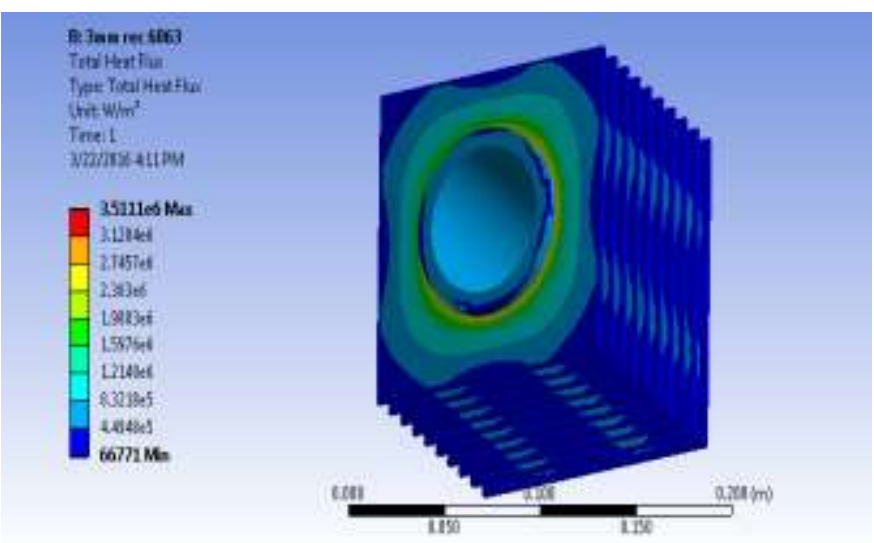

Fig -3.19: Total heat flux for Aluminum alloy 6063 at 2.5 mm thickness.

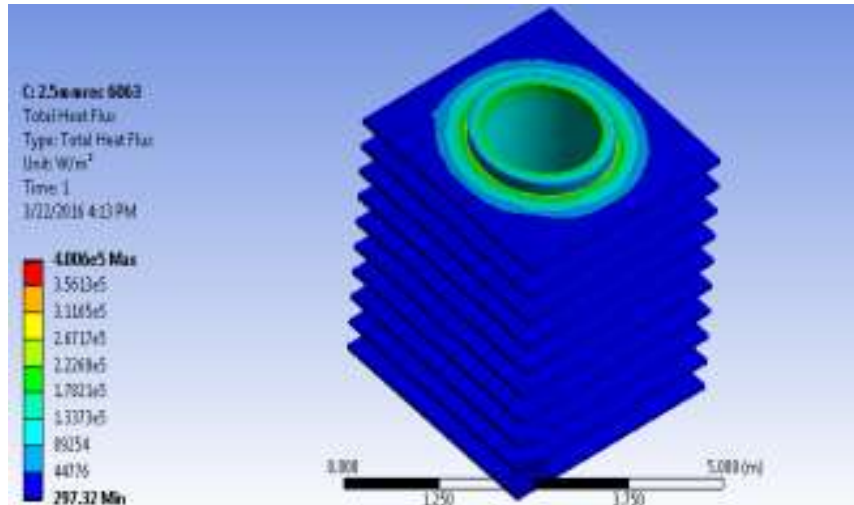

Fig -3.20: Total heat flux for Aluminum alloy 6063 at $3 \mathrm{~mm}$ thickness.

We have observed that the total heat flux change within the fin of $3 \mathrm{~mm}$ thickness is from $3.5111 * 10^{6} \mathrm{w} / \mathrm{m}^{2}$ to $66771 \mathrm{w} / \mathrm{m}^{2}$ by the flowing of air over the fin and the difference of total heat flux is $0.3827 \mathrm{w} / \mathrm{m}^{2}$. We have observed that the total heat flux change within the fin of $2.5 \mathrm{~mm}$ thickness is from $4.006 * 10^{5} \mathrm{w} / \mathrm{m}^{2}$ to $297.32 \mathrm{w} / \mathrm{m}^{2}$ by the flowing of air over the fin and the difference of total heat flux is $0.4447 \mathrm{w} / \mathrm{m}^{2}$.

\subsection{Result of Aluminum 6063Trapezoidal Fin Body with $3 \mathrm{~mm}$ and $2.5 \mathrm{~mm}$ Thickness}

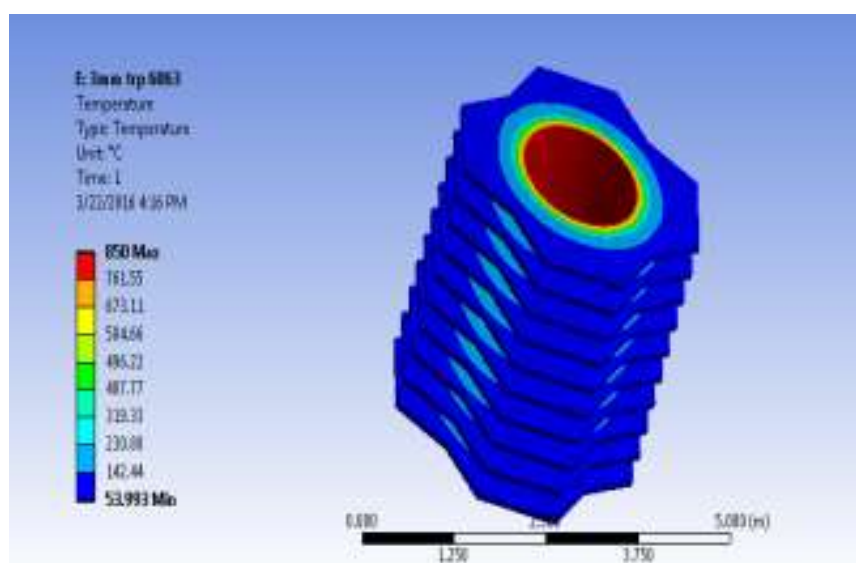

Fig -3.21: Temperature for Aluminum alloy 6063 at $3 \mathrm{~mm}$ thickness.

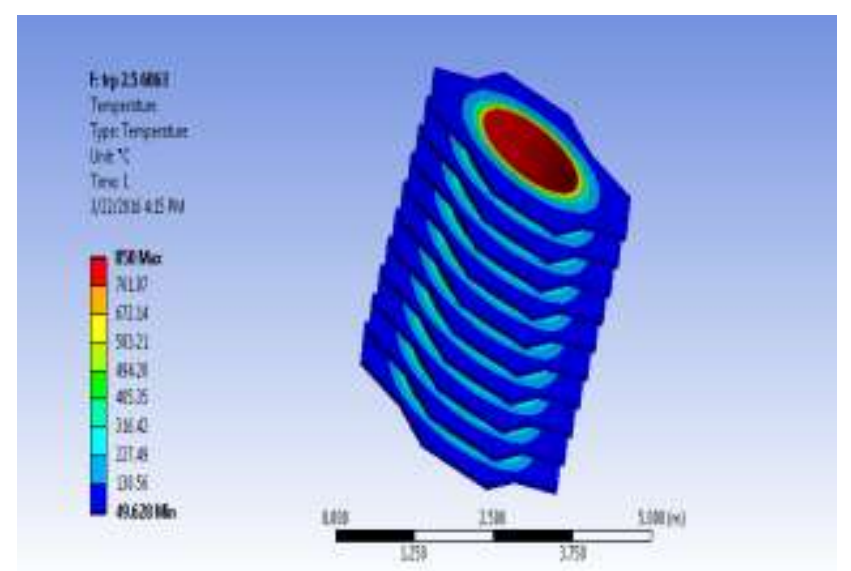

Fig -3.22: Temperature for Aluminum alloy 6063 at $2.5 \mathrm{~mm}$ thickness. 
We have observed that the temperature change within the fin of $3 \mathrm{~mm}$ thickness is from $850^{\circ} \mathrm{C}$ to $53.993^{\circ} \mathrm{C}$ by the flowing of air over the fin. Which is having a temperature gradient of $88.45^{\circ} \mathrm{C}$.We have observed that the temperature change within the fin of $2.5 \mathrm{~mm}$ thickness is from $850^{\circ} \mathrm{C}$ to $49.628^{\circ} \mathrm{C}$ by the flowing of air over the fin which is having a temperature gradient of $88.93^{\circ} \mathrm{C}$.

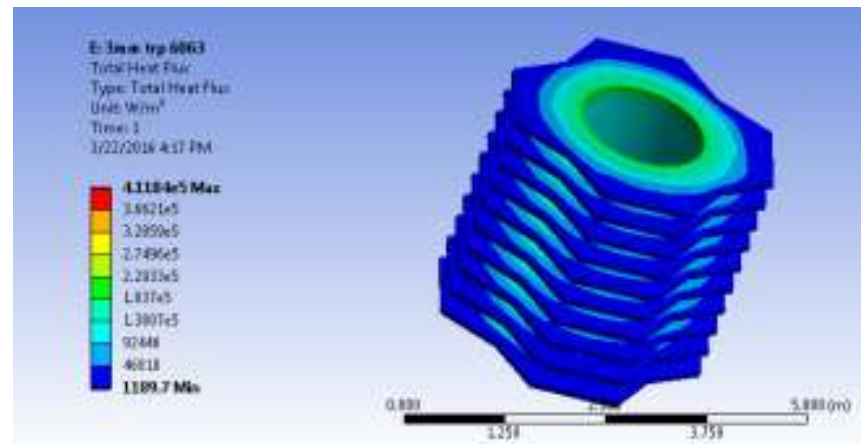

Fig -3.23: Total heat flux for Aluminum alloy 6063 at $3 \mathrm{~mm}$ thickness.

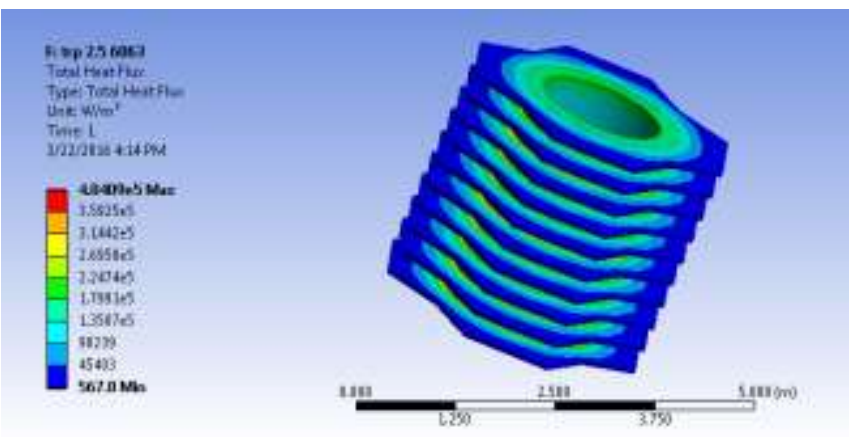

Fig -3.24: Total heat flux for Aluminum alloy 6063 at $2.5 \mathrm{~mm}$ thickness.

We have observed that the total heat flux change within the fin of $3 \mathrm{~mm}$ thickness is from $4.1184 * 10^{5} \mathrm{w} / \mathrm{m}^{2}$ to $1189.7 \mathrm{w} / \mathrm{m}^{2}$ by the flowing of air over the fin and the difference of total heat flux is $0.4563 \mathrm{w} / \mathrm{m}^{2}$.We have observed that the total heat flux change within the fin of $2.5 \mathrm{~mm}$ thickness is from $4.040 * 10^{5} \mathrm{w} / \mathrm{m}^{2}$ to $567.8 \mathrm{w} / \mathrm{m}^{2}$ by the flowing of air over the fin and the difference of total heat flux is $0.4484 \mathrm{w} / \mathrm{m}^{2}$.

\subsection{Result of Aluminum 7068 Circular Fin Body}

\section{with $3 \mathrm{~mm}$ and $2.5 \mathrm{~mm}$ Thickness}

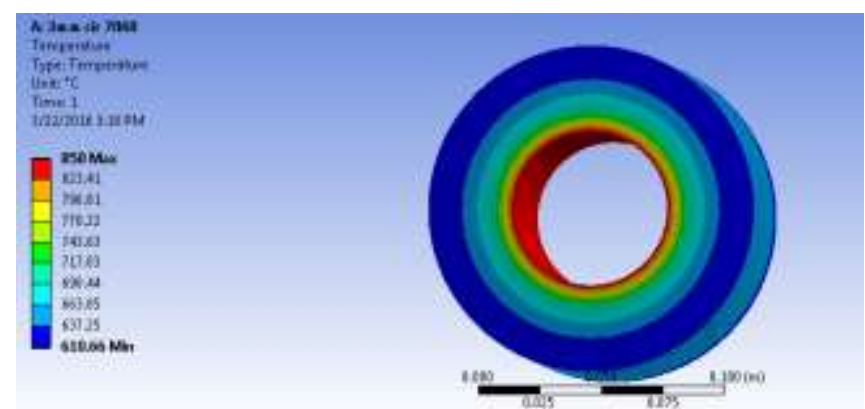

Fig -3.25: Temperature for Aluminum alloy 7068 at $3 \mathrm{~mm}$ thickness.

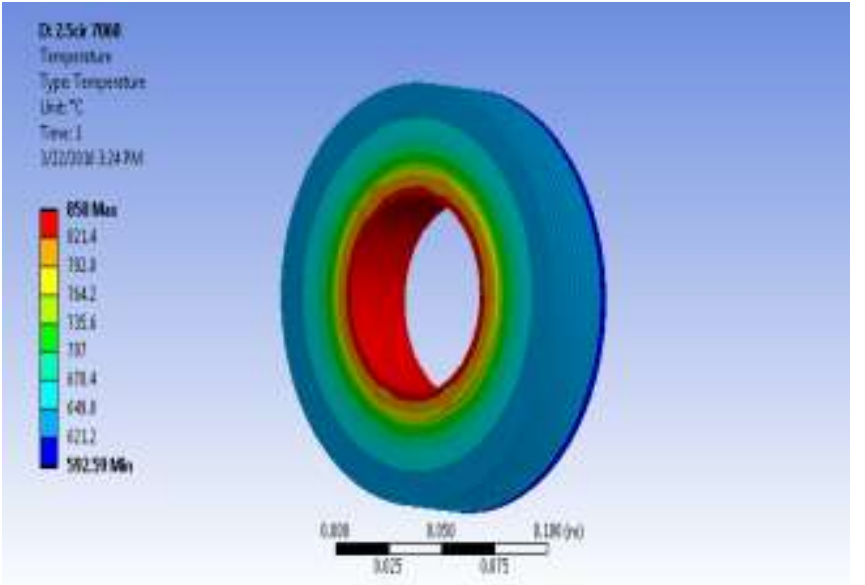

Fig -3.26: Temperature for aluminum alloy 7068 at $2.5 \mathrm{~mm}$ thickness.

We have observed that the temperature change within the fin of $3 \mathrm{~mm}$ thickness is from $850^{\circ} \mathrm{C}$ to $610.66^{\circ} \mathrm{C}$ by the flowing of air over the fin. Which is having a temperature gradient of $26.59^{\circ} \mathrm{C}$. We have observed that the temperature change within the fin of $2.5 \mathrm{~mm}$ thickness is from $850^{\circ} \mathrm{C}$ to $592.56^{\circ} \mathrm{C}$ by the flowing of air over the fin which is having a temperature gradient of $28.6^{\circ} \mathrm{C}$.

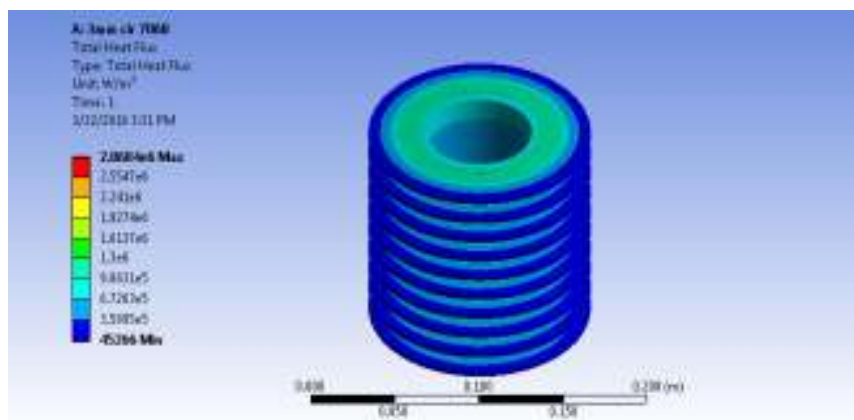

Fig -3.27: Total heat flux for Aluminum alloy 7068 at $3 \mathrm{~mm}$ thickness.

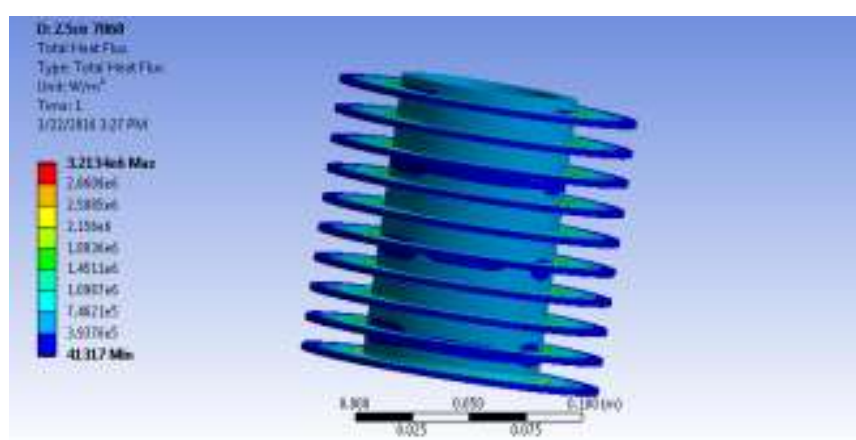

Fig -3.28: Total heat flux for Aluminum alloy 7068 at 2.5 mm thickness.

We have observed that the total heat flux change within the fin of $3 \mathrm{~mm}$ thickness is from $2.8684 * 10^{6} \mathrm{w} / \mathrm{m}^{2}$ to $45266 \mathrm{w} / \mathrm{m}^{2}$ by the flowing of air over the fin and the difference of total heat flux is $0.3137 \mathrm{w} / \mathrm{m}^{2}$.We have observed that the total heat flux change within the fin of $2.5 \mathrm{~mm}$ thickness is from $3.213 * 10^{6} \mathrm{w} / \mathrm{m}^{2}$ to $41317 \mathrm{w} / \mathrm{m}^{2}$ by the flowing of air over the fin and the difference of total heat flux is $0.3525 \mathrm{w} / \mathrm{m}^{2}$. 


\subsection{Result of Aluminum 7068 Rectangular Fin}

\section{Body with 3mm and $2.5 \mathrm{~mm}$ Thickness}

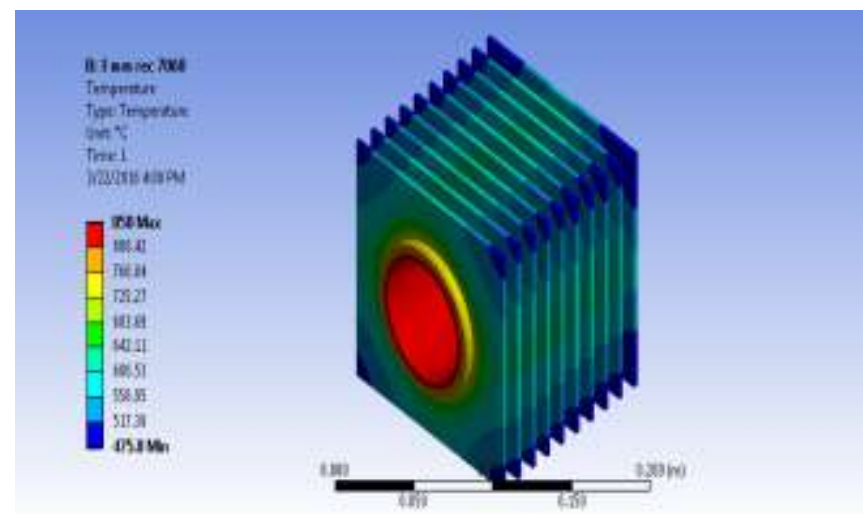

Fig -3.29: Temperature for Aluminum alloy 7068 at $3 \mathrm{~mm}$ thickness.

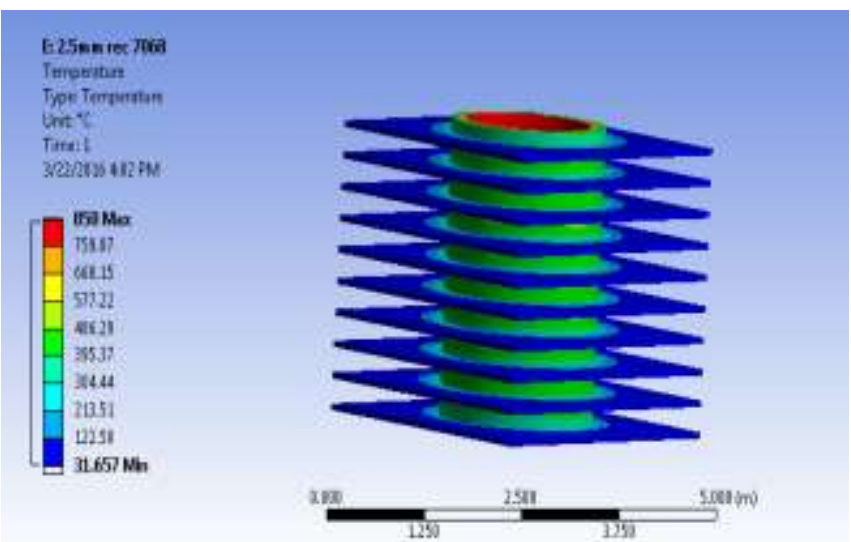

Fig -3.30: Temperature for aluminum alloy 7068 at $2.5 \mathrm{~mm}$ thickness.

We have observed that the temperature change within the fin of $3 \mathrm{~mm}$ thickness is from $850^{\circ} \mathrm{C}$ to $31.657^{\circ} \mathrm{C}$ by the flowing of air over the fin. Which is having a temperature gradient of $41.58^{\circ} \mathrm{C}$. We have observed that the temperature change within the fin of $2.5 \mathrm{~mm}$ thickness is from $850^{\circ} \mathrm{C}$ to $31.567^{\circ} \mathrm{C}$ by the flowing of air over the fin. Which is having a temperature gradient of $90.93^{\circ} \mathrm{C}$.

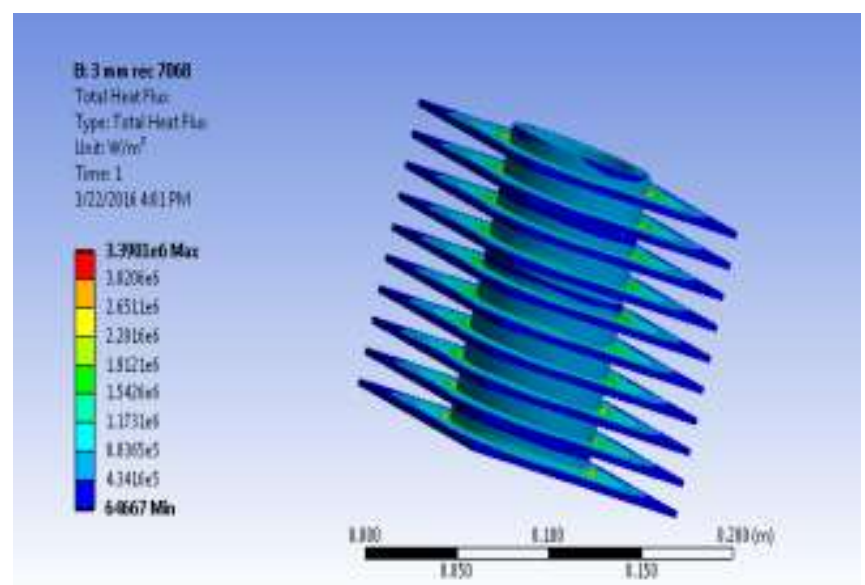

Fig -3.31: Total heat flux for Aluminum alloy7068 at $3 \mathrm{~mm}$ thickness.

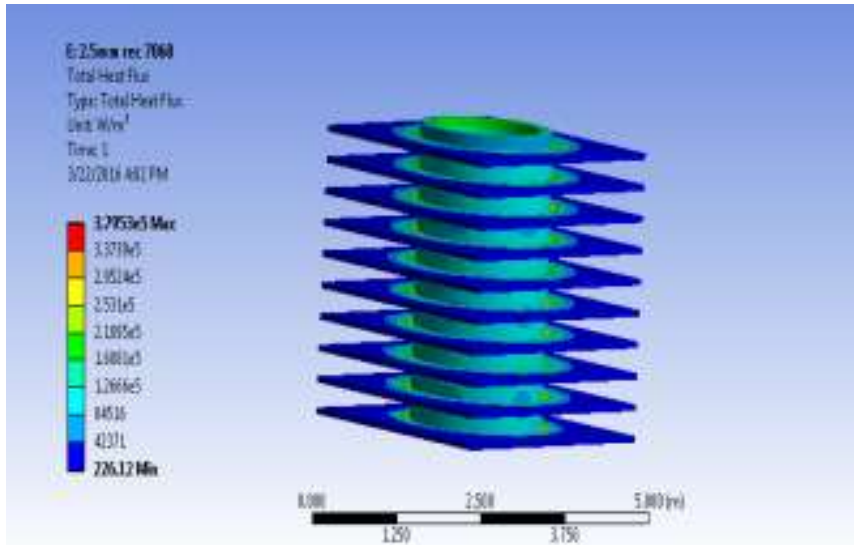

Fig -3.32: Total heat flux for Aluminum alloy7068 at 2.5 mm thickness.

We have observed that the total heat flux change within the fin of $3 \mathrm{~mm}$ thickness is from $3.795^{*} 10^{5} \mathrm{w} / \mathrm{m}^{2}$ to $226.12 \mathrm{w} / \mathrm{m}^{2}$ by the flowing of air over the fin and the difference of total heat flux is $0.3695 \mathrm{w} / \mathrm{m}^{2}$. We have observed that the total heat flux change within the fin of $2.5 \mathrm{~mm}$ thickness is from $3.795 * 10^{5} \mathrm{w} / \mathrm{m}^{2}$ to $226.12 \mathrm{w} / \mathrm{m}^{2}$ by the flowing of air over the fin and the difference of total heat flux is $0.4214 \mathrm{w} / \mathrm{m}^{2}$.

\subsection{Result of Aluminum 7068 Trapezoidal Fin}

\section{Body with $3 \mathrm{~mm}$ and $2.5 \mathrm{~mm}$ Thickness}

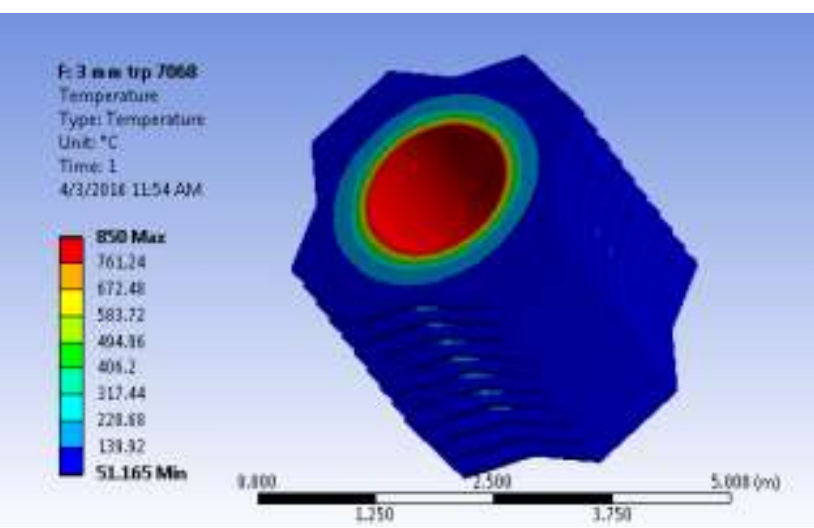

Fig -3.33: Temperature for Aluminum alloy 7068 at $3 \mathrm{~mm}$ thickness

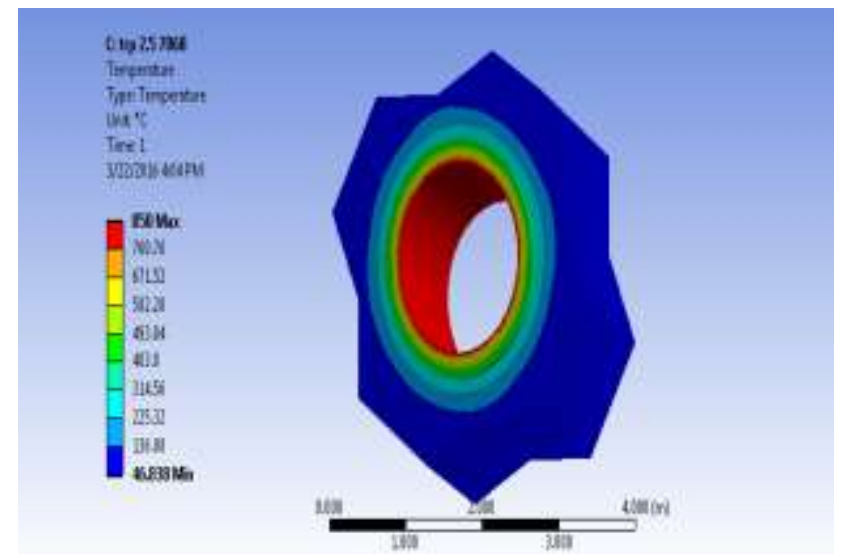

Fig -3.34: Temperature for aluminum alloy 7068 at $2.5 \mathrm{mmthickness.}$ 
We have observed that the temperature change within the fin of $3 \mathrm{~mm}$ thickness is from $850^{\circ} \mathrm{C}$ to $51.615^{\circ} \mathrm{C}$ by the flowing of air over the fin. Which is having a temperature gradient of $88.76^{\circ} \mathrm{C}$.We have observed that the temperature change within the fin of $2.5 \mathrm{~mm}$ thickness is from $850^{\circ} \mathrm{C}$ to $46.838^{\circ} \mathrm{C}$ by the flowing of air over the fin which is having a temperature gradient of $89.24^{\circ} \mathrm{C}$.

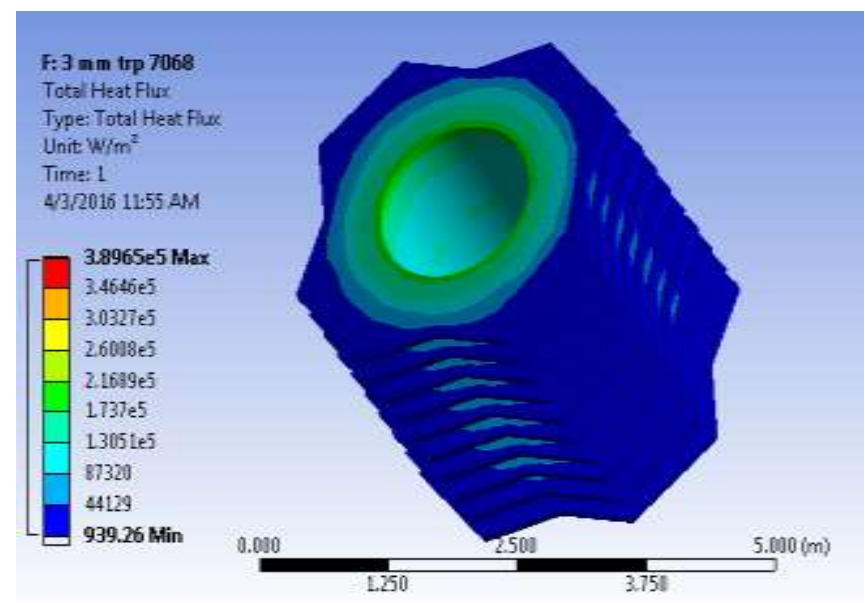

Fig 3.35: Total heat flux for Aluminum alloy 7068 at $3 \mathrm{~mm}$ thickness.

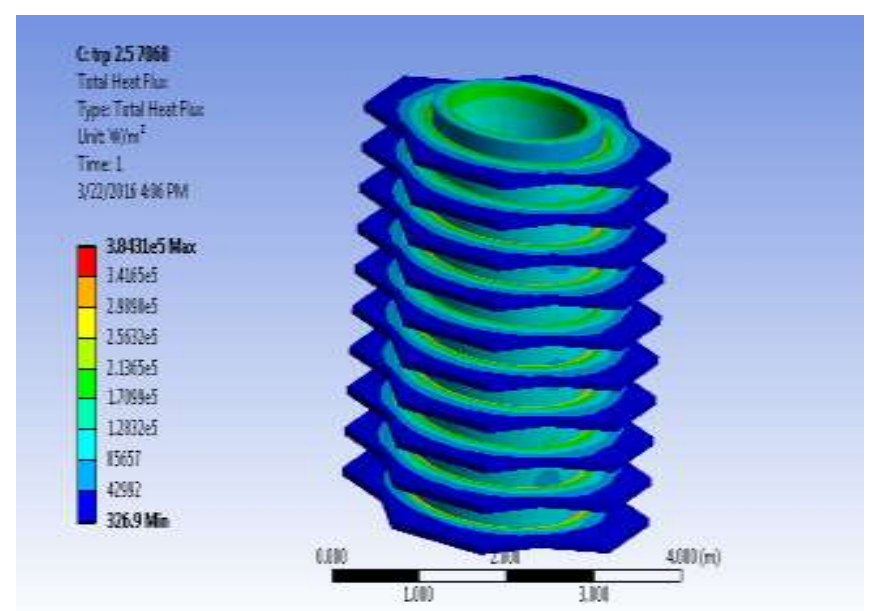

Fig -3.36: Total heat flux for Aluminum alloy 7068 at 2.5 mm thickness.

We have observed that the total heat flux change within the fin of $3 \mathrm{~mm}$ thickness is from $3.8965^{*} 10^{5} \mathrm{w} / \mathrm{m}^{2}$ to $936.25 \mathrm{w} / \mathrm{m}^{2}$ by the flowing of air over the fin and the difference of total heat flux is $0.4319 \mathrm{w} / \mathrm{m}^{2}$. We have observed that the total heat flux change within the fin of $2.5 \mathrm{~mm}$ thickness is from $38.43 * 10^{5} \mathrm{w} / \mathrm{m}^{2}$ to $326.9 \mathrm{w} / \mathrm{m}^{2}$ by the flowing of air over the fin and the difference of total heat flux is $0.4266 \mathrm{w} / \mathrm{m}^{2}$.

\section{EFFECTIVENESS OF FIN}

The performance of the fin is judged on the basis of the enhancement in heat transfer relative to the no-fin case. The performance of fin is expressed in terms of the fin effectiveness is defined as the ratio of the heat transfer rate from the fin of base area to the heat transfer rate from the surface of area i.e. It is equal to the base area of fin.

$$
\varepsilon=\frac{q_{\text {Fin }}}{q_{\text {No Fin }}}
$$

Where, $\quad \varepsilon=\quad$ Effectiveness of fin

$\begin{array}{lll}\mathrm{q}_{\text {Fin }} & = & \text { Heat flux with fin } \\ \mathrm{q}_{\text {No fin }}= & \text { Heat flux without fin }\end{array}$

Some observations with use of fins are:

$>$ An effectiveness $\varepsilon_{\text {fin }}=1$, indicates that the addition of fins to the surface does not affect the heat transfer rate at all.

$>$ An effectiveness $\varepsilon_{\text {fin }}<1$, indicates that the fin actually act as insulation and decreasing the heat transfer rate from the surface. It may occur, if fin of low thermal conductivity material is used.

$>$ An effectiveness $\varepsilon_{\text {fin }}>1$, indicates that fins are increasing the heat transfer rate from the surface.

$>$ However, the use of fins cannot be justified unless \&fin is more than 5 .

\subsection{Effectiveness of Al Alloy Circular Fin having}

\section{Thickness $2.5 \mathrm{~mm}$}

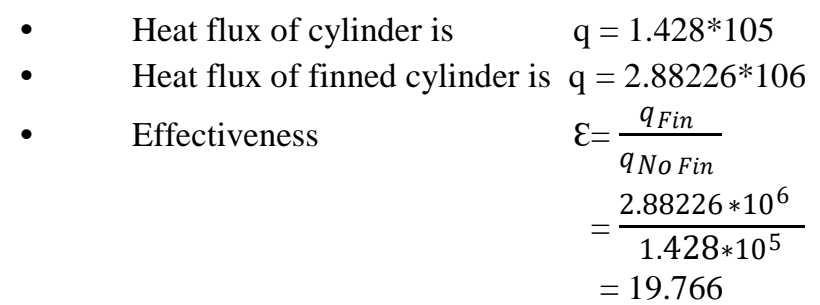

\subsection{Effectiveness of Al Alloy7068 Circular Fin}

\section{having Thickness $2.5 \mathrm{~mm}$}

- Heat flux of cylinder is

$\mathrm{q}=1.428 * 105$

- Heat flux of finned cylinder is

$\mathrm{q}=2.8998 * 106$

- $\quad$ Effectiveness

$$
\begin{aligned}
\mathcal{E} & =\frac{q_{\text {Fin }}}{q_{\text {No Fin }}} \\
& =\frac{2.8998 * 10^{6}}{1.428 * 10^{5}} \\
& =20.30
\end{aligned}
$$

\subsection{Effectiveness of Al Alloy 6063 Circular Fin}

\section{Having Thickness $2.5 \mathrm{~mm}$}

- Heat flux of cylinder is

$$
\mathrm{q}=1.428 * 10^{5}
$$

- Heat flux of finned cylinder is $\mathrm{q}=2.9938 * 10^{6}$

- $\quad$ Effectiveness

$$
\begin{array}{r}
\varepsilon=\frac{q_{\text {Fin }}}{q_{\text {No Fin }}} \\
=\frac{2.9938 * 10^{6}}{1.428 * 10^{5}} \\
=21
\end{array}
$$




\subsection{Comparision of Effectiveness:}

Table -4.1 Comparison of Effectiveness

\begin{tabular}{|c|c|c|c|}
\hline \multirow{2}{*}{$\begin{array}{c}\text { Fin } \\
\text { material }\end{array}$} & \multirow[b]{2}{*}{ Fin shape } & \multicolumn{2}{|c|}{ Effectiveness of fin } \\
\hline & & $\begin{array}{c}2.5 \mathrm{~mm} \\
\text { thickness }\end{array}$ & $\begin{array}{c}3 \mathrm{~mm} \\
\text { thickness }\end{array}$ \\
\hline \multirow{3}{*}{ Al alloy } & Circular & 19.766 & 17.88 \\
\hline & Rectangular & 2.23 & 18.6 \\
\hline & Trapezoidal & 2.083 & 1.64 \\
\hline \multirow{3}{*}{ Al 6063} & Circular & 20.964 & 18.83 \\
\hline & Rectangular & 2.44 & 19.74 \\
\hline & Trapezoidal & 2.26 & 1.79 \\
\hline \multirow[t]{3}{*}{ Al 7068} & Circular & 20.30 & 18.27 \\
\hline & Rectangular & 2.335 & 19.15 \\
\hline & Trapezoidal & 2.163 & 1.71 \\
\hline
\end{tabular}

\section{Effectiveness for selected materials at} $2.5 \mathrm{~mm}$ thickness

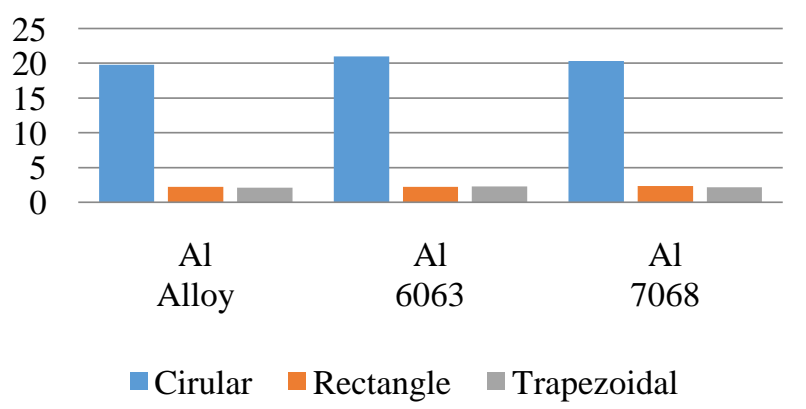

Fig -4.1: Effectiveness of selected Materials at $2.5 \mathrm{~mm}$ Thickness

\section{Effectiveness for Selected Materials at 3mm Thickness}

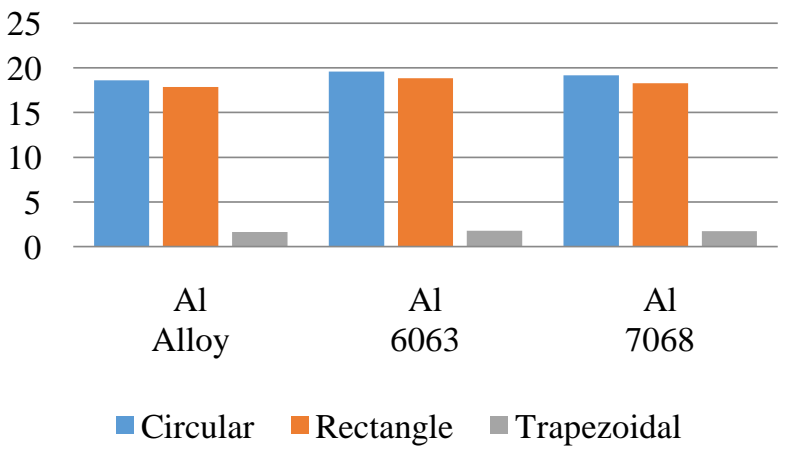

Fig -4.2: Effectiveness of Selected Material at $3 \mathrm{~mm}$ Thickness

\section{CONCLUSION}

In this project we have compared the materials aluminum alloy 6063 and aluminum alloy 7068 with general material aluminum alloy 204 with varying thickness of engine cylinder fins. The fin geometries are modeled by using AUTOCAD2016 and then thermal analysis is done on ANSYS workbench. By observing thermal analysis results, we can clearly conclude that fin material aluminum alloy 6063 of circular geometry with $2.5 \mathrm{~mm}$ thickness is most effective in terms of rate of heat flux \& effectiveness. By using circular fins with aluminum alloy 6063, the weight of the fin body is also reduces compared with the existing material of fin body.

\section{ACKNOWLEDGEMENT}

The authors can acknowledge any person/authorities in this section. This is not mandatory.

\section{REFERENCES}

[1]. Biermann, A. E. and B. Pinkel (1934). Heat Transfer from finned metal cylinders in an air stream, NACA Report No.488

[2]. J.C.Sanders, et al. (1942). Cooling test of an air-cooled engine cylinder with copper fins on the barrel, NACA Report E-103

[3]. DenpongSoodphakdee, et al. (2001). "A Comparison of Fin Geometries for Heatsinks in Laminar Forced Convection Part 1 - Round, Elliptical, and Plate Fins in Staggered and In-Line Configurations." The International Journal of Microcircuits and Electronic Packaging 24(1).

[4]. Fernando Illan and M. Alarcon (2002). "Optimization of Annular Cylindrical and Spherical Fins in an Internal Combustion Engine under Realistic Conditions." Journal of Thermal Science and Engineering Applications 2.

[5]. A. Bassam and K. A. Hijleh (2003). "Enhanced Forced Convection Heat Transfer from a Cylinder Using Permeable Fins." ASME Journal of Heat Transfer 125.

[6]. Yoshida Masao, et al. (2005). "Air-Cooling Effects of Fins on a Motorcycle Engine." Nippon Kikai GakkaiRonbunshu B Hen (Transactions of the Japan Society of Mechanical Engineers Part )

[7]. A. Mohammadi, et al. (2008). "Analysis of local convective heat transfer in a spark ignition engine." International Communications in Heat and Mass Transfer 35.

[8]. D.G.Kumbhar, et al. (2009). Finite Element Analysis and Experimental Study of Convective Heat Transfer Augmentation from Horizontal Rectangular Fin by Triangular Perforations. Proc. of the International Conference on Advances in Mechanical Engineering.

[9]. N.Nagarani and K. Mayilsamy (2010). "EXPERIMENTAL HEAT TRANSFER ANALYSIS ON ANNULAR CIRCULAR AND ELLIPTICAL FINS." International Journal of Engineering Science and Technology 2(7): 2839-2845.

[10]. A. T. Pise and U. V. Awasarmol (2010). "Investigation of Enhancement of Natural Convection Heat Transfer from Engine Cylinder with Permeable Fins." International Journal of Mechanical Engineering \& Technology (IJMET) 1(1): 238-247.

\section{BIOGRAPHIES}

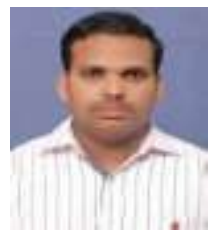

Mr. N.Srinivasa Rao, Assistant Professor, Shri Vishnu Engineering College for Women, Bhimavaram, West Godavari District, Andhra Pradesh-534202. 


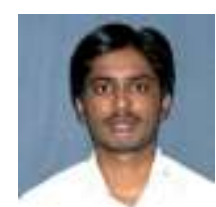

Mr. G.V.Subhash, Assistant Professor,

Shri Vishnu Engineering College for Women, Bhimavaram, West Godavari District, Andhra Pradesh-534202

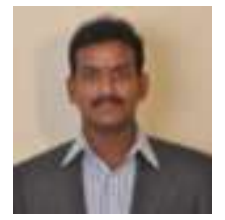

Mr. K.Ashok Kumar, Assistant Professor, Shri Vishnu Engineering College for Women, Bhimavaram, West Godavari District, Andhra Pradesh-534202.

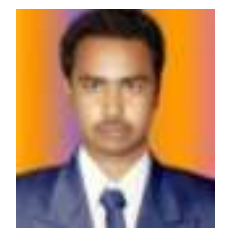

Mr. B.N. Malleswara Rao, Assistant Professor, Shri Vishnu Engineering College for Women, Bhimavaram, West Godavari District, Andhra Pradesh-534202. 